$$
\begin{aligned}
& \text { WORKING PAPERS } \\
& \text { No. 29/2014 (146) } \\
& \text { GRAŻYNA BUKOWSKA } \\
& \text { JAN FAŁKOWSKI } \\
& \text { BEATA ŁOPACIUK-GONCZARYK }
\end{aligned}
$$

\title{
TEAMING UP OR WRITING ALONE - AUTHORSHIP STRATEGIES IN LEADING POLISH ECONOMIC JOURNALS
}




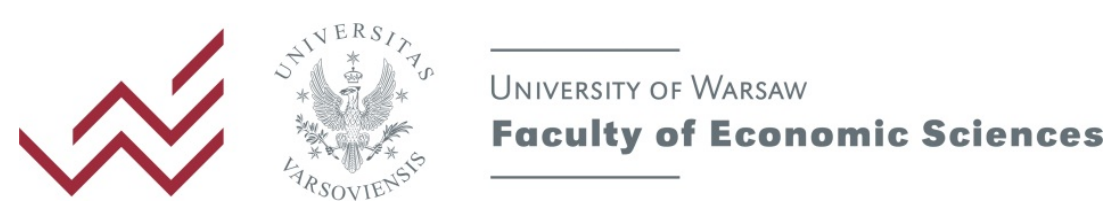

\title{
Teaming up or writing alone - authorship strategies in leading Polish economic journals
}

\author{
GRAŻYNA BUKOWSKA \\ Faculty of Economic Sciences \\ University of Warsaw \\ e-mail: gbukowska@uw.edu.pl
}

\author{
JAN FAŁKOWSKI \\ Faculty of Economic Sciences \\ University of Warsaw \\ e-mail: jfalkowski@wne.uw.edu.pl
}

\author{
BEATA LOPACIUK-GONCZARYK \\ Faculty of Economic Sciences \\ University of Warsaw \\ e-mail: bgonczaryk@wne.uw.edu.pl
}

\begin{abstract}
The returns to scientific collaboration have been widely acknowledged. The general trend observed in top scientific journals is an increase in collaborative activities both between researchers and between institutions, especially with regard to international co-authorship. Not only there is a growing number of papers written in co-authorship, but also there is an increase in the number of co-authors. In this paper, we investigate whether similar tendencies have emerged in the scientific community of economists in Poland. Using social network analysis, we focus on collaboration between researchers publishing in five leading Polish economic journals. We find that both the number of articles written in collaboration and average number of authors per article are steadily increasing. Yet, compared to what we observe in western economic journals, the scale of collaboration is modest. Furthermore, the increase in collaborative activity which we observe is not followed by a rise in collaboration with foreign co-authors.
\end{abstract}

Keywords:

co-authorship network, Polish economic journals, collaboration strategies, scientific productivity

JEL:

I23, D85, Z13, D02

\section{Acknowledgements}

This paper was prepared as a part of a research grant "Collaboration and publications in top journals - determinants of Polish scientists' productivity in discipline of economics" carried out at Faculty of Economic Sciences, University of Warsaw, founded by the National Science Centre (decision no DEC-2011/03/B/HS4/01531). We would like to thank Marek Żukowski for support in preparation of a data base. Sole responsibility for the research outcomes and all their constraints and weaknesses are ours. 


\section{INTRODUCTION}

In Poland, similarly like in other countries, scientific productivity is becoming more and more assessed based on publications in reputable journals. This applies to every science and economics, which is the focus of this study, is not an exception. Publication record strongly affects academic institutions' and their employees' ability to get funds for scientific research (Bukowska and Łopaciuk-Gonczaryk 2013). This phenomenon is related to a growing pressure for publishing in high-impact-factor journals.

This obviously presents a challenge for authors to find and implement an optimal publication strategy. There is no doubt that a scientist's output largely depends on his/her ability and effort. Yet, as it is shown by the existing literature, an important determinant of scientific performance is also an individual's research network (see, for example, Wuchty et al. 2007; Azoulay et al. 2010; Waldinger 2010; De Stefano et al. 2013). Positive relationship between a researcher's publication record and social interactions can be expected at least on two grounds. First, functioning in the research network is likely to facilitate early access to new ideas. Second, collaboration may be beneficial due to increasing returns to specialization and the need to combine ideas and skills to produce new quality in science (Jones 2009; Agrawal et al. 2013).

While the benefits from collaboration between researchers seem to be fairly universal, the actual patterns of behaviour in terms of cooperation may differ across countries, disciplines, research institutions or journals. In response to this, the present paper asks to what extent cooperative equilibria have emerged in Polish science. The focus of this paper is on economics. In particular, we examine behaviour of Polish authors in terms of cooperation when publishing in five leading Polish economic journals: Argumenta Oeconomica, Bank $i$ Kredyt, Ekonomista, Gospodarka Narodowa and Polityka Społeczna. We measure collaboration reflected in the co-authorship of a published paper. Clearly, this indicator of actual cooperative behaviour is not flawless (Benett and Taylor 2003; Lee and Bozeman, 2005). Yet, it is commonly accepted and widely used in the literature (Goyal et al. 2006; Moody 2004; Newman 2004; Fafchamps et al. 2006; Acedo et al. 2006). The analysis covers all articles published in the selected journals between 1999 and 2012. While the decision to look at these five journals was to some extent arbitrary, it was dictated by three important considerations. First, we focused on journals published at least since 1999, so those that have some history of established reputation. Second, we assumed that most influential papers are published in general interest journals rather than in field-specific journals (and consequently excluded from the analysis journals specializing in, for example, rural affairs or logistics). Third, we chose journals that over the period 1999-2012 were most frequently marked by the Polish Ministry of Science with the best evaluation. Therefore, if we assume that the Ministry's evaluation system reflects journals' quality and prestige, we focus on journals with highest average quality and prestige. What should also be noted, for publications in these journals (in comparison with other Polish economic journals) researchers received, on average, the highest possible number of points which were later used for their assessment at their parent research institutions. In effect, from scientists' point of view, publishing in these five journals could have been perceived as relatively more valuable than publishing in other Polish journals.

To best of our knowledge, this paper is the first to study social interactions reflected in the co-authorship of a published paper in Polish economic journals. In fact, analyses of scientific publications (both in domain of economics and in other domains) in Polish literature are still 
rare and limited. Existing works in this area focus on comparing publishing performance of different research institutions (eg. Kierzek 2008 and 2009; Wróblewski 2005), methods of measuring such performance (Osiewalska 2008), problems connected with evaluating scientists based on citation indexes (Błocki and Życzkowski 2013) and difficulties to evaluate journals (Wilkin 2013). There are also only a few analyses of publishing successes' determinants (Wolszczak-Derlacz and Parteka 2010; Bukowska and Łopaciuk-Gonczaryk 2013) and the role of collaboration between scientists (Olechnicka and Płoszaj 2008; Łopaciuk-Gonczaryk 2014). One of the reasons of the small coverage of this topic, especially in case of more in-depth empirical analyses, is the lack of complete databases of articles in Polish journals and affiliations of their authors.

This paper attempts to fill this gap at least to some extent. By doing so, we aim to contribute not only to the Polish literature on the subject, but also to a broader literature focusing on co-authorship, its prevalence, development in time and differences between journals (see, among others, Goyal et al. 2006; Moody 2004; Newman 2004; Fafchamps et al. 2006; Acedo et al. 2006). Other studies relevant to our paper investigate the role of collaboration in increasing productivity in science, especially in the context of observed growth of its complexity and specialization (Wuchty et al. 2007; De Stefano et al. 2013). A lot of researches show that collaboration in science is increasing (De Stefano et al. 2013; Moody 2004; Acedo et al. 2006). Furthermore, the analyses demonstrate not only the rise in the number of co-authored papers, but also an increase in the number of co-authors (Goyal et al. 2006; Wuchty et al. 2007) and a growth in international collaborations (Adams et al. 2005). It is interesting therefore to see, whether similar trends characterize also publishing process in economic journals in Poland. Finally, our paper is also related to a literature on social interactions and the role that the latter play in shaping individual's behaviour (see, for example, Bramoulle et al. 2009; Calvo-Armengol et al. 2009; Fafchamps et al. 2010).

The fact that the analysis focuses on Poland provides yet another advantage. As noted in other studies, research in Central and Eastern European Countries (CEECs) has had to face many problems, resulting in rather poor scientific performance, especially during the years around the breakdown of the communist regimes (Egorov 2002; Yegorov 2009; Kozak et al., 2013).

That said, especially in recent years, organization of science in Poland has been strongly reoriented and focused on improving scientific performance measured, to a large extent, by publication records (Bukowska and Łopaciuk-Gonczaryk 2013). In this context, particularly given the evidences on positive relationship between collaboration and publication output mentioned above, our analysis may provide some insights about the evolution of more cooperative equilibrium in the situation where history-determined social norms could have strongly affected the motivation of researchers to cooperate with each other.

We believe that the analysis presented here may be of relevance for researchers, research institutions and the scientific authorities as it may be directly related to the debate about changes in the legislation regulating the functioning of Polish science (adopted so far and the possible directions of their further evolution). Last but not least it may also be useful for journal editors. Definitely, a more in-depth analysis should follow and complement the picture. However, a starting point, i.e. describing the current situation as far as the cooperative activities of economists publishing in leading Polish economic journals are concerned, needs to be done. We hope that this paper may act as a first step in that wider project. 
The paper is organised as follows. It starts with a brief review of the literature on coauthorship trends in world economic journals and scientific collaboration in CEECs. Later the choice of data and data sources is explained. In the third section, we present the analysis of trends and patterns in co-authorship for five Polish economic journals: Argumenta Oeconomica, Bank i Kredyt, Ekonomista, Gospodarka Narodowa and Polityka Społeczna, covering the time period from 1999 to 2012. Finally the results are discussed and summarized.

\section{CO-AUHORSHIP TRENDS IN ECONOMIC JOURNALS}

Since the first decades of the 20th century publication in economics has expanded rapidly. Indeed, the cumulative stock of journal articles in economics has doubled every fourteen years (Schymura 2012). Numerous empirical studies have examined the production of scientific knowledge in economics, patterns of co-authorship for individual economists, the development of co-authorship in certain economic subfields or the major economic journals (see, for example: Goyal et al. 2006; Acedo at al. 2006, Fafchamps et al. 2006). A lot of researchers paid attention to a rising incidence and extent of co-authorship in economic publications (Goyal et al. 2004 and 2006; Laband and Tollison 2000; Laband et al. 2002; Card and DellaVigna 2013; Hamermesh 2013). For example, Laband and Tollison (2000) show that in "three prominent economics journals: the American Economic Review, the Journal of Political Economy, and the Quarterly Journal of Economics, the percentage of co-authored papers grew between 1950 and 1994, less than 10\% in the 1950s and around 70\% in 1994." This is consistent with the results of Cosme Costa Vieira (2008), who found for a sample of 168 journals in the economics in the ISI database, $47 \%$ of papers were multi-authored (two or more authors) between 1986 and 1996.

Goyal et al. (2004 and 2006) analysed sample of articles published in the past three decades and considered all papers published in journals listed by EconLit to confirm empirical evidence on the evolution of the world of journal publishing economists. They found that in the 1970's the world of economics was a collection of islands, with the largest island (component) having about $15 \%$ of the population and in the 1990's economists were more integrated, with the largest island covering close to half the population. Their research confirm an increased collaboration in economics. Trend showing a growing rate of coauthored papers can be observed in case of all journals listed in Econlit, but it is especially evident in 5 general economics journals with the highest average impact factors (American Economic Review, Econometrica, Journal of Political Economy, Quarterly Journal of Economics, and Review of Economic Studies) (compare tab. 1 and 2.).

Table 1. Summary statistic for all articles in Econlit

\begin{tabular}{|l|l|l|l|}
\hline Period & $1970 \mathrm{~s}$ & $1980 \mathrm{~s}$ & $1990 \mathrm{~s}$ \\
\hline total papers & 62569 & 95027 & 156454 \\
\hline author per paper & & & \\
\hline single-authored & .753 & .678 & .578 \\
\hline two authors & .210 & .256 & .309 \\
\hline three authors & .031 & .055 & .090 \\
\hline four or more authors & .005 & .011 & .023 \\
\hline
\end{tabular}

Source: Goyal et al. 2004 
Table 2. Summary statistic for all articles in American Economic Review, Econometrica, Journal of Political Economy, Quarterly Journal of Economics and Review of Economic Studies

\begin{tabular}{|l|c|l|l|}
\hline Period & $1970 s$ & $1980 s$ & $1990 s$ \\
\hline total papers & 5023 & 4565 & 3705 \\
\hline author per paper & & & \\
\hline single-authored & .743 & .604 & .458 \\
\hline two authors & .225 & .330 & .424 \\
\hline three authors & .029 & .059 & .099 \\
\hline four or more authors & .003 & .007 & .019 \\
\hline
\end{tabular}

Source: Goyal et al. 2004

Card and Della Vigna (2013), who cover all publications from 1970-2012 in the American Economic Review, Quarterly Journal of Economics, Journal of Political Economy, Econometrica and the Review of Economic Studies, showed that the number of authors per paper in economics has grown steadily from the early 1970s, when $75 \%$ of articles were single-authored and the average of authors in a paper was 1.3. By the early 1990s the fraction of single authored papers had fallen to $50 \%$, and the mean number of authors reached 1.6. Most recently, in 2011-2012, more than three quarters of papers have at least 2 authors and the mean number of author is 2.2.

To best of our knowledge, co-authorship trends in economics in case of Central and Eastern European Countries are rather poorly documented. Several studies have analysed the research productivity and potential for economists from the region to contribute to the international literature, but surprisingly little is known about their publication strategies and potential role that social interactions may play in improving their publication records. Transition has resulted in a multiplication of economic journals, as each institution launched its own publications or journal. The impact of the majority of these was proved negligible (Csaba 2002). Such publications are financed by given departments, which publish mainly their own faculty's work, and have other local faculty serving as reviewers. This solution is certainly not conducive to warranting publication quality. Another part of explanation is that demanding methods of research performance evaluation have not yet became an established part of academic culture in transition countries. First steps in this direction appeared during the last decade. A partial analysis of publications of Czech economists during 1993-2000 was prepared by Turnovec (2002). A survey of thematic orientation of economic articles published by authors from the Czech Republic in comparison to the rest of Europe can be found in Macháček (2004). Although we can list some researches on publishing outcomes of economists from CEECs, the literature on domestic production in the context of co-authorships exists only in country languages and therefore comparisons here are difficult.

However, the evidence on collaboration that exists for other social sciences in transition countries is fairly consistent with the picture sketched above, referring to the trends in world economics. For example, in their study on sociologists in Slovenia, Mali et al. (2010) showed that during the period between 1986 and 2005 there was an increase in the number of coauthored publications. In particular, the percentage of single authorships dropped from roughly $80 \%$ to roughly $40 \%$, whereas the average number of authors, for scientific articles, increased from slightly more than one to around 1.75 . 
While any generalizations about the performance of economists from transition countries might seem unfair, it seems undisputable that the great majority of them tend to publish in domestic and international low quality journals, i.e. in journals with low impact factor. To illustrate this, one may recall the fact that in the period 1993-2004 in CEECs and Russia around $75 \%$ and $45 \%$ respectively of economic papers were published in low quality journals (Ciaian and Pokrivcak 2005). This obviously, inclines one to ask to what extent the process of convergence in research productivity (between the transition countries and the West) have taken place or may take place in the future.

The constraints faced by researchers in transition countries are usually more stringent. Private mechanisms of funding are not as widespread as in more developed countries and the level of public funding is low and may be the only option for a scientist. Furthermore, the production of knowledge is usually affected by poor infrastructure conditions for scientific research, short-planning horizon brought on by budget constraints and low-quality research institutions. Therefore, research collaboration and the consolidation of networks could be even more relevant for these countries. We can distinguish different types of collaboration: (a) domestic in-house collaboration (all authors from the same affiliation); (b) domestic institutional collaboration (all authors from the same country but from more than one affiliation); and (c) international collaboration (authors from more than one country) (Leimu and Koricheva 2005). While, as mentioned before, there are hardly any studies related to scientific collaboration between economists in transition countries, below we briefly review the literature on the region documenting various trends in collaboration of scientists in general. The evidence available is especially on international collaboration, which is assumed by researchers to be the most important catching-up strategy.

Table 3. Share of internationally co-authored papers in 2009

\begin{tabular}{|l|c|c|c|c|c|}
\hline & Bulgaria & $\begin{array}{c}\text { Czech } \\
\text { Republic/Slovakia }\end{array}$ & Hungary & Poland & Romania \\
\hline Natural and life sciences & 0.536 & 0.431 & 0.520 & 0.335 & 0.317 \\
\hline Social sciences & 0.615 & 0.195 & 0.452 & 0.267 & 0.218 \\
\hline Arts \& humanities & 0.143 & 0.044 & 0.142 & 0.102 & 0.164 \\
\hline
\end{tabular}

Source: Teodorescu and Andrei 2011

After 1989 an increase in collaboration has been observed for all CEECs. This growth has been driven in part by the expansion of domestic publications that are indexed by ISI and by the growing number of collaborations with scholars from western countries. The increase in co-publishing varies between scientific fields, which is an observation valid for all the regions. For example, Larivie're et al. (2006), looking at the period 1986-2002 for Canada, found that natural sciences and social sciences have witnessed a steady growth in the share of co-authored publications, due to increased collaboration with both international and domestic colleagues. At the same time, similar trend could not be observed in the humanities, where the share of co-publication has stayed fairly low. Also for transition countries, co-authorship seems to be the strongest in natural sciences followed by social sciences and humanities. There is evidence that the share of internationally co-authored papers in natural sciences ranges from $31.7 \%$ in Romania to more than $50 \%$ in Hungary and Bulgaria, while for social sciences it is generally lower, starting with $19.5 \%$ for Slovakia, but peaking at $61.5 \%$ in Bulgaria (which is an exception to the rule that collaboration in social sciences is lower than in natural sciences, table 3., Teodorescu and Andrei 2011). 
Interestingly, two countries that enjoy the highest levels of international collaboration in social sciences (Bulgaria and Hungary), also enjoy high level of co-authorship in natural sciences. For social sciences in Poland, international collaboration is at medium level, and it is higher than in Czech Republic/Slovakia and Romania.

It is worth mentioning here that in natural and life sciences, international collaboration has been historically seen as a self-evident part of research and therefore was much more common. In these fields, research often requires access to expensive equipment or mass of colleagues working around the same scientific problem. In social sciences, internationalization has rather been seen as a possibility for cross-cultural dissemination of research ideas (Hakala 1998). Furthermore, in social sciences researchers work often on national and local problems. In addition, they often aim their publications to domestic journals. As a result, papers in this domain, are relatively more frequently authored by researchers from one country (Puuska at all. 2014).

As far as other determinants of scientific collaboration are concerned, Gossart and Ozman (2009) and Must (2012) showed that small countries are more active in international collaboration than in domestic collaboration and that the share of international copublications is bigger in their overall scientific production than in big countries. In addition, they argue that geographical, linguistic, cultural, political, and geopolitical factors as well as bilateral or multilateral agreements between countries or institutions all have an effect on the degree and direction of international research cooperation. In similar spirit, Ukrainski et al. (2014) argued that the scientific size of a nation determines the need for international collaboration. According to their argument, small states are less homogenously collaborating with all countries in the European research system and their intra-national research cooperation is also more fragmented. In addition, smallness of a country is viewed as a constraint for building up domestic human and financial resources for science and expertise in different fields, even for a critical mass of domestic R\&D. In consequence, countries with lower degrees of material and intellectual resources are more likely to look for research partners outside national borders than resource-rich countries. Differences in domestic and international collaboration patterns across countries can also be explained by their location in the scientific centre or the periphery. Goldfinch et al. (2003) found that countries in scientific periphery benefit from international collaboration while domestic collaborations between institutions in these countries have a negative relationship with citation rates (see also Schubert and Sooryamoorthy 2010).

Finally it is worth referring to the study for the three Baltic states, namely Estonia, Latvia and Lithuania, in which Allik (2003) showed that different countries with the same starting positions could develop over the years different trajectories with different scientific performances and collaboration. In this view, collaboration is related to the increasing practice of universities, ministries and funding agencies evaluating scientific performance through bibliometric indicators. One of the explanations for the weaker international coauthorships in social sciences, arts, and humanities could be that the domestic journals satisfy the need for scholarly communication in these fields, and naturally within domestic journals the role of foreign collaboration is small. It is also possible that the evaluation and promotion systems in the different fields do not incentivize publishing in international publications in the same way.

With this description in hand, we now move to investigate the patterns of scientific collaboration among Polish economists in the chosen domestic journals, where we mainly 
expect national collaborations. The analysis comes shortly after a brief presentation of the data.

\section{DATA SOURCES}

An analysis presented below is based on data on all articles (up to 6 co-authors, 1999-2012, both in Polish and in foreign languages) from five leading Polish economic journals: "Argumenta Oeconomica" (AE), "Bank i Kredyt” (BK), „Ekonomista” (E), "Gospodarka Narodowa" (GN), and "Polityka Społeczna" (PS). Articles with pure foreign affiliation have been excluded with exception of 5 articles and 5 authors. Those 5 foreign authors are coauthors of Polish authors in case of other articles, so information on their collaboration record has been included as relevant for network analysis. This decision has led to exclusion to 158 pure-foreign affiliated articles and, consequently, 190 foreign authors ( $84 \mathrm{AE}, 60 \mathrm{BK}$, $6 \mathrm{E}, 23 \mathrm{GN}, 19 \mathrm{PS})$.

The data were obtained from BazEkon. Missing articles were added based on journals archives. Affiliations were obtained directly from articles' body. In some cases it was achieved through on-line access, but in most of the cases it was obtained from hard copies in a library. However there were a lot of blanks, especially in earlier years, and affiliations differed between articles of authors with the same name and surname. Therefore, to identify the authors and establish their main affiliations, two additional data sources were used: NAUKA POLSKA \& POL-on. Access to those data sources enabled not only filling in missing affiliations or deciding between conflicting affiliations but also including scientific titles in the analysis. This way we could also distinguish between authors with the same name and surname (and sometimes even from the same affiliation) or avoid (at least to some extent) treating authors with a change in surname (women after marriage) as different ones. Authors were treated as Polish, if after identification it had been found that they had Polish affiliation. In the analyses presented below the main affiliation was decided based on the up-to-date information in POL-on, in case of missing data or doubts connected with author identification, it was completed and verified by the data from affiliations given in articles, the data from NAUKA POLSKA and web pages of universities.

\section{TRENDS IN CO-AUTHORSHIP IN FIVE LEADING ECONOMIC JOURNALS IN POLAND (1999- 2012)}

The empirical strategy that we use is based on social network analysis (SNA) (Scott 2000; Wasserman and Faust 2008). The perspective of SNA is focused on structure of relationship (ties) between interacting individuals (nodes) and assumes that this structure of interactions creates opportunities and constraints, both on the level of structural positions of egos and on the level of the whole network. There is a broad literature using SNA in researches on scientific collaboration. They explore its patterns and trends (eg. Newman 2004; Acedo et al. 2006), its determinants (eg. Fafchamps et al. 2010) and the influence of co-authorship strategies on publication successes (eg. McFadyen and Cannella 2004; Kuzhabekova 2011; Rumsey-Wairepo 2006). Our focus is on a researcher's ego-network which encompasses all his co-authors while taking into consideration all the articles in collaboration. The number of articles written together by two authors is treated as tie strength. The implication is a division of scientists into solitary (no collaboration at all) and collaborating ones (having a network of co-authors at least of size one, which means collaborating with at least one researcher in the time period under study, in form of one or more articles). Another 
consequence is an opportunity to look at the composition of ego-networks, to explore the level of homophily (collaborating with similar authors, e.g. in terms of gender). Furthermore, at macro level, we analyse the whole network structure, taking into consideration the level of its fragmentation and the share of giant component (the biggest group of mutually connected scientists). Additionally, we will look at trends in collaboration statistics. Furthermore we will explore differences between the journals and inquire into different types of collaboration: within-department, domestic inter-department and international one. Wherever it is possible, we will try to refer our findings to other researches.

To start with we look at general statistics describing our data (table 4.). First of all, we can notice that in case of all Polish journals considered, articles having only one author prevail.

Table 4. Sum of articles with different numbers of authors - Argumenta Oeconomica, Bank i Kredyt, Ekonomista, Gospodarka Narodowa and Polityka Społeczna 1999-2012

\begin{tabular}{|l|c|c|c|c|c|c|}
\hline & $\begin{array}{c}\text { Argumenta } \\
\text { Oeconomica }\end{array}$ & $\begin{array}{c}\text { Bank i } \\
\text { Kredyt }\end{array}$ & Ekonomista & $\begin{array}{c}\text { Gospodarka } \\
\text { Narodowa }\end{array}$ & $\begin{array}{c}\text { Polityka } \\
\text { Społeczna }\end{array}$ & in total \\
\hline no of authors: \\
\hline 1 author & 101 & 771 & 390 & 475 & 897 & $\mathbf{2 6 3 4}$ \\
\hline 2 authors & 32 & 152 & 82 & 94 & 117 & $\mathbf{4 7 7}$ \\
\hline 3 authors & 9 & 27 & 19 & 19 & 12 & $\mathbf{8 6}$ \\
\hline 4 authors & 1 & 3 & 4 & 2 & 3 & $\mathbf{1 3}$ \\
\hline 5 authors & 0 & 0 & 1 & 1 & 1 & $\mathbf{3}$ \\
\hline 6 authors & 0 & 0 & 0 & 0 & 1 & $\mathbf{1}$ \\
\hline in total & $\mathbf{1 4 3}$ & $\mathbf{9 5 3}$ & $\mathbf{4 9 6}$ & $\mathbf{5 9 1}$ & $\mathbf{1 0 3 1}$ & $\mathbf{3 2 1 4}$ \\
\end{tabular}

Secondly, we look at authors' characteristics and inquire who is involved in co-authorship and who decides to write only as a solitary author (table 5.). Although these numbers do not allow for drawing any definite conclusions, several interesting observations emerge that could be further developed in future research. First, we observe that scientists starting their career ( $m g r$ - masters of sciences, mostly Phd candidates) are among collaborating authors more often than the other groups. A potential explanation is that one strategy which junior faculty can use to develop a research stream is to work collaboratively. It can be argued that younger researchers will be motivated to publish with co-authors in order to achieve a higher productivity and position in the hierarchy of the university (He 2009), while senior researchers, whose position is already stabilized, have no such pressure (Lissoni 2011). Collaboration provides a learning opportunity for a scientist to acquire skills and knowledge not otherwise available from partners. In this case, a person in a senior position may be less co-working, because the system of evaluation and promotion does not work or in the past did not work properly (Lissoni et al. 2011). However this does not explain, why full professors (prof. $d r h a b$.) collaborate only slightly less often that doctors ( $d r)$ and assistant professors/associate professors ( $d r$ hab.), who still have to work for their further promotions. Possible explanation here is that Phd candidates collaborate with their supervisors, who are different kinds of professors (prof. $d r h a b$. and $d r h a b$.). Nevertheless in case of our data only 11 out of 21 collaborating master of sciences ( $m g r$ ) have a professor (a $d r$ hab. or a prof. $d r$ hab.) as a collaborator and 9 of them have also other co-authors in their 
networks. Therefore it is reasonable to conclude that scientists on different levels of academic hierarchy have various incentives to collaborate. Junior researchers do it working for promotion and seeking expertise from higher positioned colleagues, while the latter benefit from those collaborations by having a support in their researches and making a good use of their professional network built during longer time in academia (Abramo at al., 2011).

Table 5. Solitary and collaborating authors versus scientific title and gender - all five journals together, 1999-2012

\begin{tabular}{|c|c|c|c|c|}
\hline $\begin{array}{c}\text { Polish authors } \\
\text { (scientific title } \\
\text { in 2012) } \\
\end{array}$ & $\begin{array}{c}\text { collaborating } \\
\text { authors }\end{array}$ & $\begin{array}{l}\text { solitary } \\
\text { authors }\end{array}$ & $\begin{array}{c}\text { average share of co- } \\
\text { authors of the same } \\
\text { gender }\end{array}$ & in total \\
\hline $\mathrm{mgr}$ & $21(60 \%)$ & $14(40 \%)$ & $58 \%$ & 35 \\
\hline female & $10(59 \%)$ & 7 (41\%) & $49 \%$ & 17 \\
\hline male & $11(61 \%)$ & 7 (39\%) & $67 \%$ & 18 \\
\hline$d r$ & $347(42 \%)$ & 477 (58\%) & $65 \%$ & 824 \\
\hline female & $143(38 \%)$ & $234(62 \%)$ & $50 \%$ & 377 \\
\hline male & 204 (46\%) & 243 (54\%) & $72 \%$ & 447 \\
\hline dr hab. & 134 (44\%) & $169(56 \%)$ & $59 \%$ & 303 \\
\hline female & $40(33 \%)$ & $82(67 \%)$ & $44 \%$ & 122 \\
\hline male & 94 (52\%) & 87 (48\%) & $70 \%$ & 181 \\
\hline prof. dr hab. & $116(41 \%)$ & 170 (59\%) & $73 \%$ & 286 \\
\hline female & 38 (39\%) & 59 (61\%) & $65 \%$ & 97 \\
\hline male & $78(41 \%)$ & 111 (59\%) & $80 \%$ & 189 \\
\hline unidentified & $140(42 \%)$ & 197 (58\%) & $62 \%$ & 337 \\
\hline female & $75(46 \%)$ & 89 (54\%) & $48 \%$ & 164 \\
\hline male & $65(38 \%)$ & $108(62 \%)$ & $69 \%$ & 173 \\
\hline in total & $758(42 \%)$ & $1027(58 \%)$ & $61 \%$ & 1785 \\
\hline
\end{tabular}

We can also notice, that female doctors $(d r)$ and assistant professors/associate professors ( $d r$ hab.) choose solitary strategies more often than their male colleagues. Their participation in publishing is also more modest (table 5.). The last conclusion can be also made for women with full professor title (prof. $d r$ hab.). In the literature we often find evidence that regardless of discipline, women publish significantly fewer articles than men (Fox 2005). A difference between women and men in productivity is also accompanied by a difference in the level of co-authorship. McDowell and Smith (1992) found a choice of coauthor in a cohort of PhD holders in economics to be significantly influenced by their gender. Furthermore, they found also that propensity for single authorship was higher among women than men. Various authors argue also that these differences affect promotion decisions to the disadvantage of women. Boschini and Sjögren (2007) examined articles from three top economics journals (1991-2002), and confirmed that co-author seeking behaviour is not neutral in regard to gender. Women are twice as likely to co-author with women than men are. Additionally, single authorship among women decrease over time. In fields with higher percentages of women authors, woman-woman co-authored articles are more frequent. Research on the development of mentoring relationships provides a possible explanation for gender differences in collaborative research. The scarcity of women 
occupying the upper ranks in an organization creates gender differences in access to mentors. Women have to develop cross-gender relationships, while their male peers do not. Even if potential male mentors have positive attitudes toward women, research suggests that male mentors will choose male assistants because personal identification is a key element in the selection process (Welsh and Bremser 2005). In case of our data, an average ego has $61 \%$ of his co-authors of the same gender as himself/herself. Furthermore, for all scientific titles, selection based on the same gender is especially characteristic for men, who tend to have higher share of male co-authors than women do of female ones (table 5.). Additionally, in order to test formally, if we observe a selection process based on homophily in case of gender, we have applied QAP correlation (procedure available in UCINET), which enables to correlate matrices and is based on permutation tests of significance. Therefore it is especially appropriate to be used for network data, which naturally are not random samples (Borgatti et al. 2013). We have obtained a significant correlation (with p-value of 0.0002), which is a confirmation that tendency observed in the Polish journals for scientists to choose co-authors of the same gender is not spurious.

To make any conclusions about the level of collaboration in the 5 top Polish economic journals during 1999-2012 we need a reference point. As it has been already noted, we did not find any analysis using economic journals from the countries of our region, but we may use data for the best western journals as comparison. Therefore we consider 5 top world economic journals (American Economic Review, Econometrica, Journal of Political Economy, Quarterly Journal of Economics, and Review of Economic Studies - Goyal et al. 2004) for the ten-year period of 90-ties, averages for all journals listed in Econ-Lit for the same period (Goyal et al. 2004) and 10 top journals in Management for 1980-2002 (Academy of Management Journal, Academy of Management Review, Administrative Science Quarterly, Journal of Management, Management Science, Organization Science, Strategic Management Journal, Organization Studies, Journal of Management Studies, Human Relations., Acedo et al. 2006). Our data are more up-to date than the reference sets, but taking into consideration (as it has been discussed above) that world trends in co-authorship are growing and that CEECs have to catch-up, it should not create a serious problem. In case of Polish journals we observe (table 6.) small rate of co-authored articles (even smaller than the rate of $25 \%$ for an average journal in Econ-Lit in the time period 70 -ties - compare table 1. - and much smaller than the rates from the 90-ties given as reference), small average number of authors per article (in comparison with Acedo et al.'s study on managerial journals) and small share of collaborating authors (less than a half, when in the other studies it is $70 \%$ and more). Components are parts of network which are not connected between themselves. SNA researches pay a special interest to a giant (largest) component, which is the component of the biggest size indicating what part of all authors is integrated. In case of Polish journals giant component contains only $3 \%$ of all authors and $8 \%$ of collaborating authors which is very little comparing to the reference studies. 
Table 6. Descriptive and network statistics in comparison with earlier studies regarding top western journals

\begin{tabular}{|c|c|c|c|c|}
\hline & Our study & $\begin{array}{c}\text { Goyal et al., } \\
2004\end{array}$ & $\begin{array}{c}\text { Goyal et al., } \\
2004\end{array}$ & $\begin{array}{c}\text { Acedo et al., } \\
2006\end{array}$ \\
\hline Time period & 1999-2012 & 90-ties & 90-ties & 1980-2002 \\
\hline No of journals & 5 & 5 & at least 687 & 10 \\
\hline No of articles & 3214 & 3705 & 156454 & 11022 \\
\hline No of authors & $\begin{array}{c}1875 \text { (including } \\
1785 \text { Polish } \\
\text { authors) }\end{array}$ & 3171 & 81217 & 10176 \\
\hline $\begin{array}{c}\text { Mean no of } \\
\text { articles per } \\
\text { author }\end{array}$ & $\begin{array}{l}2.09 \text { ( } 2.13 \text { per } \\
\text { Polish author) }\end{array}$ & 1.87 & 2.83 & 2.04 \\
\hline $\begin{array}{c}\text { Rate of co- } \\
\text { authored papers }\end{array}$ & $18 \%$ & $54 \%$ & $42 \%$ & - \\
\hline $\begin{array}{c}\text { Average no of } \\
\text { authors per } \\
\text { paper }\end{array}$ & 1.22 & - & - & 1.88 \\
\hline $\begin{array}{c}\text { No of } \\
\text { collaborating } \\
\text { authors }\end{array}$ & 848 & 2470 & 56639 & 8830 \\
\hline $\begin{array}{l}\text { Percentage of } \\
\text { collaborating } \\
\text { authors among } \\
\text { all authors }\end{array}$ & $45 \%$ & $78 \%$ & $70 \%$ & $87 \%$ \\
\hline $\begin{array}{c}\text { Giant } \\
\text { component size }\end{array}$ & 65 & 779 & 33027 & 4625 \\
\hline $\begin{array}{c}\text { Giant } \\
\text { component as a } \\
\text { percentage of } \\
\text { all authors } \\
\text { (collaborating } \\
\text { authors only) }\end{array}$ & $3 \%(8 \%)$ & $25 \%(32 \%)$ & $41 \%(58 \%)$ & $45 \%$ (52\%) \\
\hline
\end{tabular}

Table 7. lists some additional descriptive statistics for our data and shows, among others, that an average number of articles per author is higher in case of collaborating authors than solitary authors. 
Table 7. Additional descriptive statistics - Argumenta Oeconomica, Bank i Kredyt, Ekonomista, Gospodarka Narodowa and Polityka Społeczna (1999-2012)

\begin{tabular}{|l|l|}
\hline No of authors: & 1875 \\
\hline No of Polish authors: & 1785 \\
\hline No of foreign co-authors of Polish authors: & 44 \\
\hline No of unidentified authors: & 46 \\
\hline No of Polish cooperating authors: & 758 \\
\hline $\begin{array}{l}\text { average no of articles written by Polish } \\
\text { cooperating author: }\end{array}$ & $2.59(\mathrm{MIN}=1 ; \mathrm{MAX}=27)$ \\
\hline No of Polish solitary authors: & 1027 \\
\hline $\begin{array}{l}\text { average no of articles written by Polish } \\
\text { solitary author: }\end{array}$ & $1.79(\mathrm{MIN}=1 ; \mathrm{MAX}=24)$ \\
\hline No of Polish affiliations: & 408 \\
\hline $\begin{array}{l}\text { No of Polish affiliations of cooperating } \\
\text { authors only: }\end{array}$ & 220 \\
\hline
\end{tabular}

Figure 1. Five Polish leading journals - network of collaborating authors

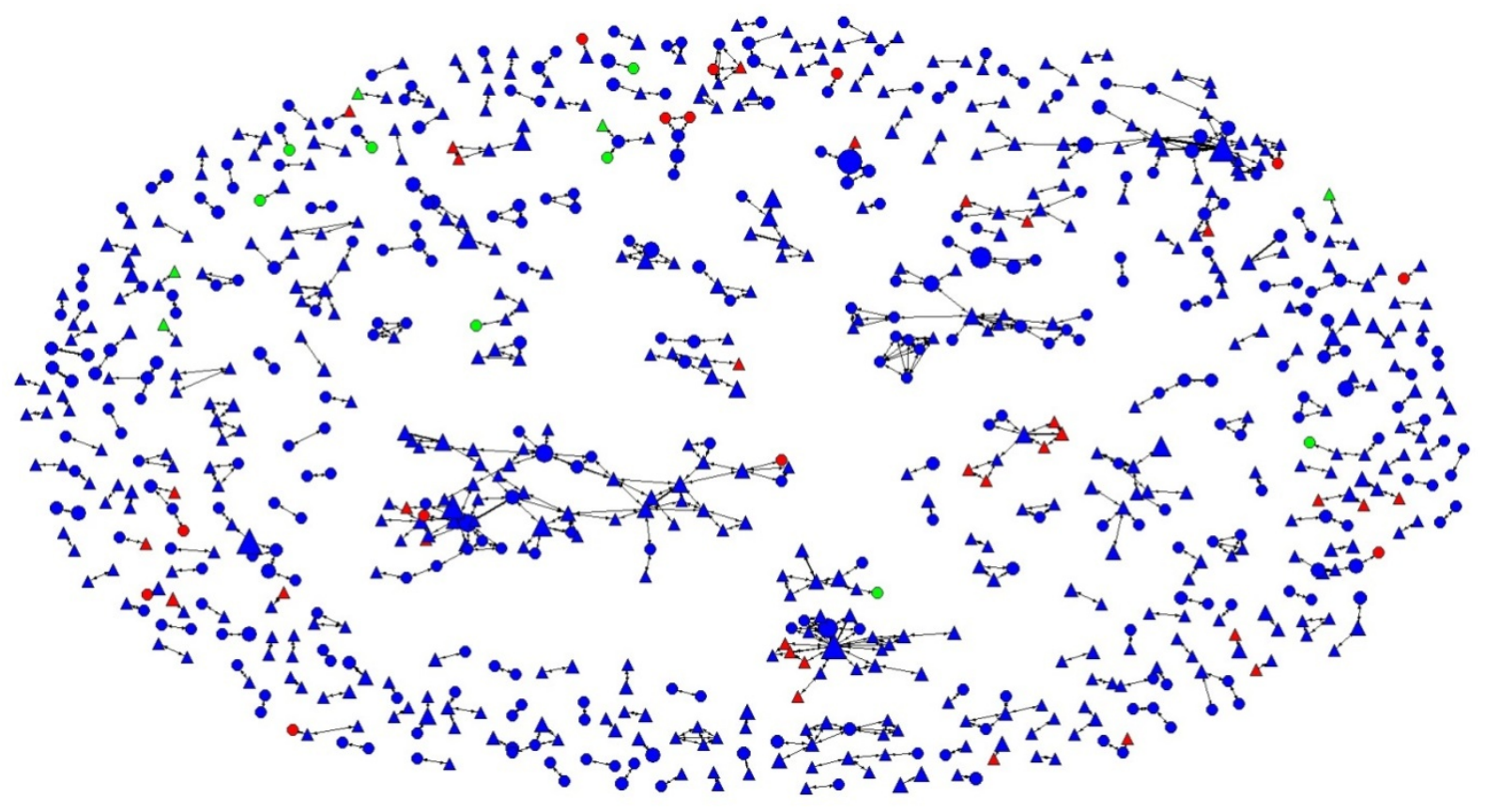

Figure 1. illustrates network of collaborating authors in 5 Polish journals grouped together, between 1999-2012. Node size corresponds to sum of articles published by the author. Triangles are men and circles are women. All Polish scientists are marked navy blue, red nodes are authors with foreign affiliation and green are those with not identified affiliation. Line size means tie strength, bolder lines are for acts of repetitive collaboration between the 
authors. The network is very sparse, consists of 260 components in total with 174 components ( $57 \%$ of all collaborating authors) of size 2 , which means that the dominating form of collaboration is one-time co-authorship of only two researchers. The network's fragmentation is 0.989 , which is very high and means proportion of nodes that cannot reach each other.

The next step is to look at the collaboration trends in time. Based on the literature presented above, we expect that even if co-authorship rates are low, they should increase in time. It turns out that it is really so, as the rate of co-authored articles in first 7 years (1999-2005) is $15 \%$ and it rises to $22 \%$ in the second half of the period under study (2006-2012). Similarly, share of collaborating authors in the period increases from $35 \%$ to $46 \%$ and size of giant component rises from $3 \%$ to $5 \%$ (in reference to all authors collaborating in the period). This is visualized in table 8 .

Table 8. Comparisons between 1999-2005 and 2006-2001 - descriptive and network statistics for all five journals in total

\begin{tabular}{|l|c|c|}
\hline Time period: & $1999-2005$ & $2006-2012$ \\
\hline $\begin{array}{l}\text { No of authors } \\
\text { publishing in the } \\
\text { period }\end{array}$ & 1147 & 1068 \\
\hline $\begin{array}{l}\text { No of collaborating } \\
\text { authors in the period }\end{array}$ & $\begin{array}{c}\text { (excluding isolates in this } \\
\text { period) }\end{array}$ & $\begin{array}{c}496 \text { (excluding isolates in this } \\
\text { period) }\end{array}$ \\
\hline $\begin{array}{l}\text { Percentage of } \\
\text { collaborating authors } \\
\text { among all authors }\end{array}$ & $35 \%$ & $46 \%$ \\
\hline No of articles & 1784 & $22 \%$ \\
\hline $\begin{array}{l}\text { Rate of co-authored } \\
\text { articles }\end{array}$ & $15 \%$ & 26 \\
\hline $\begin{array}{l}\text { Size of largest } \\
\text { component: }\end{array}$ & $3 \%$ & $5 \%$ \\
\hline $\begin{array}{l}\text { Size of largest } \\
\text { component as a } \\
\text { percentage } \\
\text { collaborating authors }\end{array}$ & 11 & \\
\hline
\end{tabular}

Figure 2. enables a more detailed analysis of changes in time. It illustrates trends in collaboration for all Polish journals together. As it turns out, similarly to trends in the literature discussed above, we can observe an increase of collaboration in time (both share of articles in collaboration and average number of authors per article grow). However the cooperation structure does not change, as around half of articles in collaboration is coauthored by researchers from the same affiliation (faculty). Furthermore, share of articles including foreign co-authors is very low and stable over time. What is also interesting, trends for articles written in Polish are very similar to trends observed for articles written in other languages, which means that the increase in collaboration is not caused by a rising share of articles in foreign languages. 
Figure 2. Collaboration trends in 5 Polish journals totally: 1999-2012
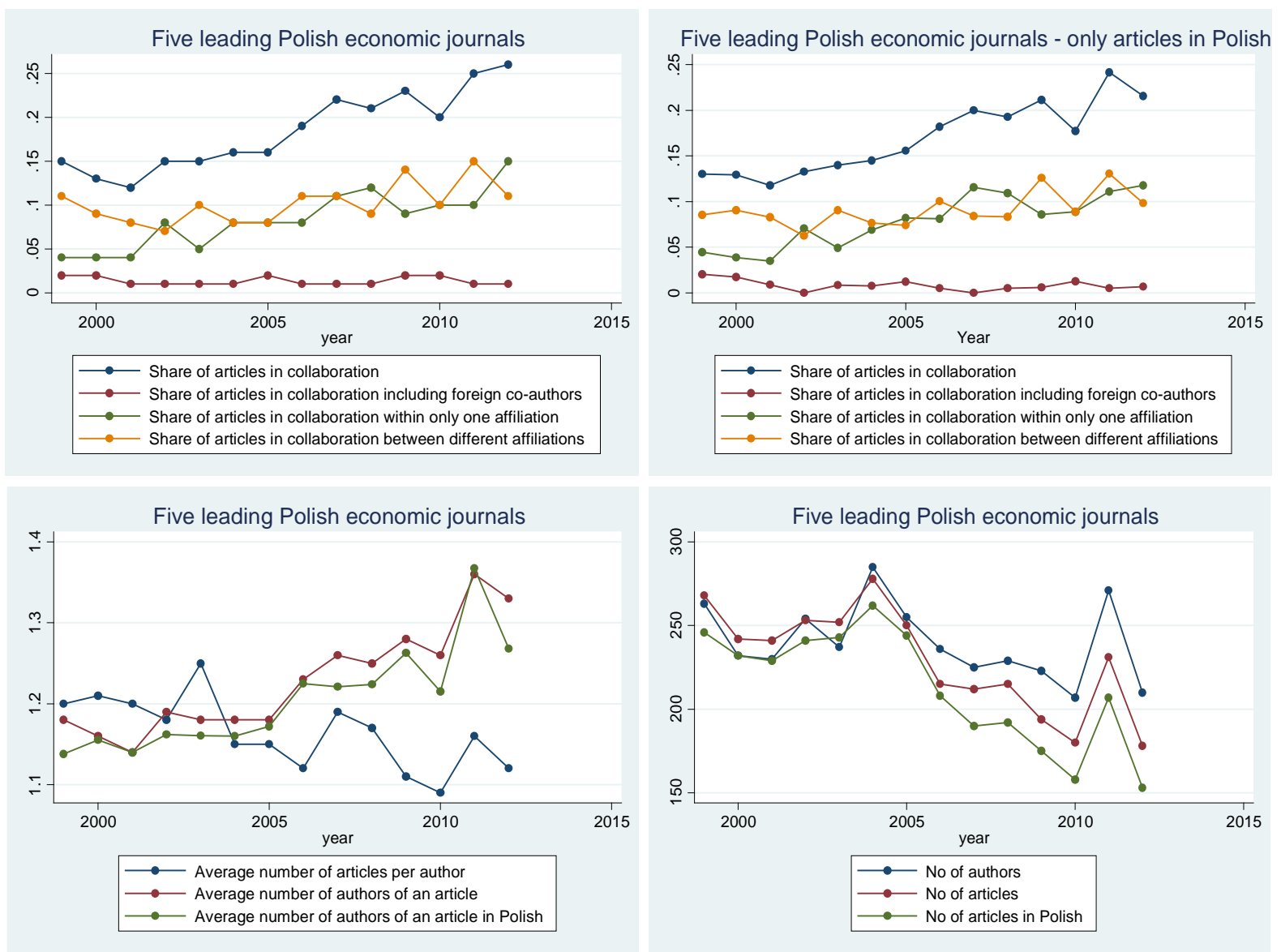

So far we have mostly analysed collaboration in all the journals in total. It is interesting to see what are the differences between the journals. Trends in time, analogical to those presented in figure 2., are enclosed as supplementary data below, as they yield less consistent picture as the trends for all journals in total (it may be connected with the fact, that for some years our samples for some journals are very small). More clear is figure 3 . which depicts percentage of articles having only one author (no collaboration), percentage of articles having at least one co-author with foreign affiliation (foreign collaboration), percentage of articles having all authors from the same affiliation (all authors from the same affiliation) and percentage of articles in collaboration, with no co-authors with foreign affiliation and having at least two authors from different faculties - at the same or at different universities - or from other different affiliations, eg. National Bank of Poland and Faculty of Economics, University of Warsaw (other national collaboration). As it can be concluded, Argumenta Oeconomica is a leader in terms of all types of collaboration. It has especially comparatively high share of foreign collaboration. 
Figure 3. Types of collaboration in different journals

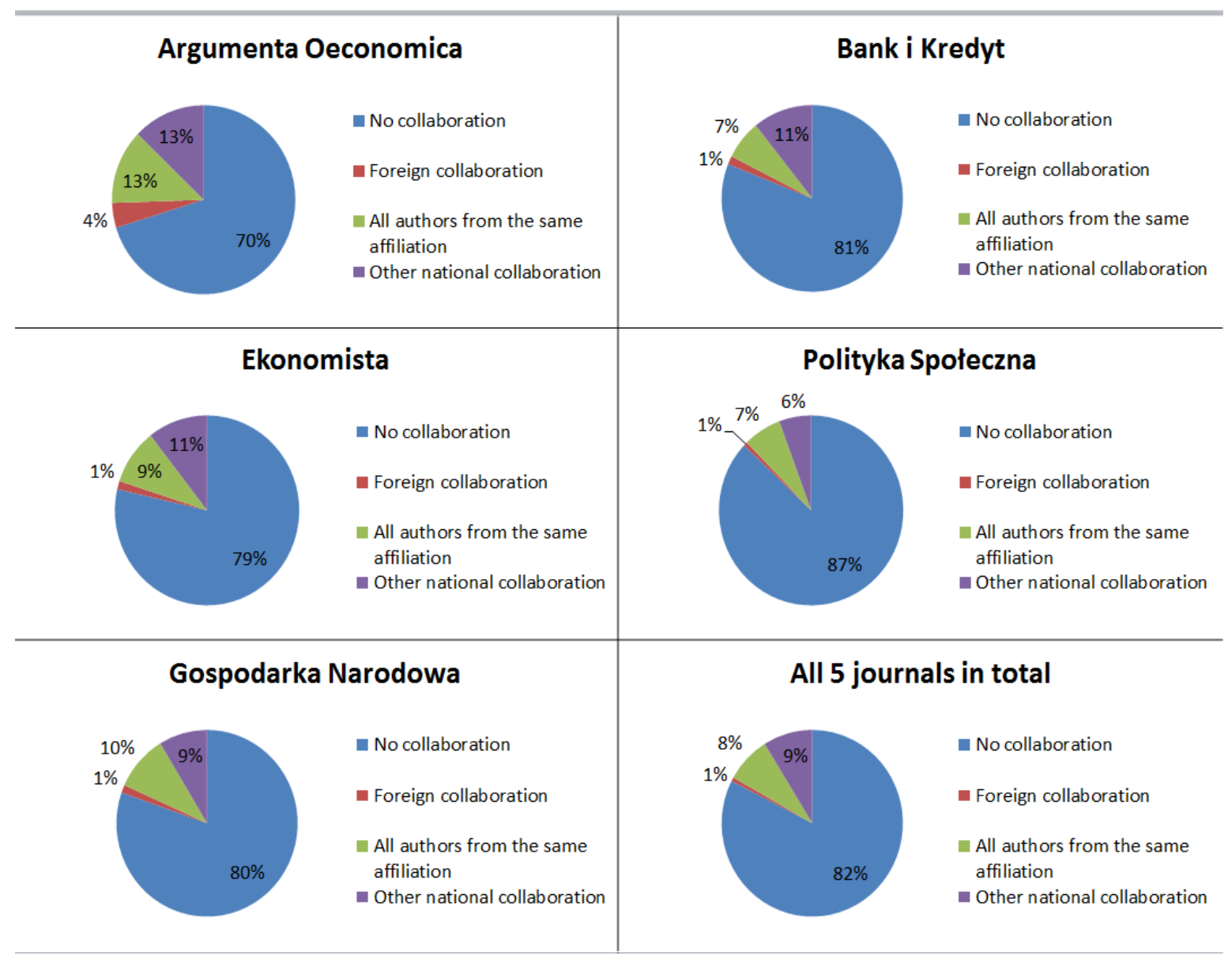

Further comparisons can be made based on table 9. Argumenta Oeconomica is the only journal where the number of collaborating authors exceeds the number of solitary authors (collaboration as a co-authorship within a given journal). The highest share of solitary authors (almost two times as much as collaborating authors) can be observed in Polityka Społeczna. It can be noticed that Argumenta Oeconomica is the only journal where all articles are in English, and Polityka Społeczna is the only journal where all articles are in Polish. However network of Argumenta Oeconomica is very disconnected and of small biggest component. It should be noted though, that the number of articles in this journal in the whole period is very low in comparison to other journals (especially Bank i Kredyt and Polityka Społeczna). Bank i Kredyt and Polityka Społeczna can be compared as having similar number of authors and articles. It can be noticed that Bank i Kredyt has more collaboration: higher share of collaborating authors, higher rate of co-authored articles and bigger size of largest component. Networks of Ekonomista and Gospodarka Narodowa are similar, but in Ekonomista there is a higher share of authors who are collaborating authors. 
Table 9. Comparisons between five Polish journals - descriptive statistics

\begin{tabular}{|c|c|c|c|c|c|}
\hline Journal & $\begin{array}{l}\text { Argumenta } \\
\text { Oeconomica }\end{array}$ & \begin{tabular}{|ll} 
Bank & i \\
Kredyt & \\
\end{tabular} & Ekonomista & $\begin{array}{l}\text { Gospodarka } \\
\text { Narodowa }\end{array}$ & $\begin{array}{l}\text { Polityka } \\
\text { Społeczna }\end{array}$ \\
\hline No of Polish authors: & 157 & 588 & 363 & 408 & 635 \\
\hline $\begin{array}{l}\text { No of foreign co- } \\
\text { authors of Polish } \\
\text { authors: }\end{array}$ & 6 & 16 & 10 & 8 & 8 \\
\hline $\begin{array}{l}\text { No of unidentified } \\
\text { authors }\end{array}$ & 0 & 39 & 0 & 0 & 9 \\
\hline $\begin{array}{l}\text { No of Polish } \\
\text { cooperating (within } \\
\text { the analysed journal) } \\
\text { authors: }\end{array}$ & 83 & 254 & 162 & 163 & 221 \\
\hline average no of articles: & $\begin{array}{c}1.17 \\
(\mathrm{MIN}=1 \\
\mathrm{MAX}=3)\end{array}$ & $\begin{array}{c}2.20 \\
(\mathrm{MIN}=1 \\
\mathrm{MAX}=15) \\
\end{array}$ & $\begin{array}{c}1.80 \\
(\mathrm{MIN}=1 ; \\
\mathrm{MAX}=13) \\
\end{array}$ & $\begin{array}{c}2.16 \\
(\mathrm{MIN}=1 ; \\
\mathrm{MAX}=14)\end{array}$ & $\begin{array}{c}2.21 \\
(\mathrm{MIN}=1 ; \\
\mathrm{MAX}=25)\end{array}$ \\
\hline $\begin{array}{l}\text { No of Polish solitary } \\
\text { (within the analysed } \\
\text { journal) authors: }\end{array}$ & 74 & 334 & 201 & 245 & 414 \\
\hline average no of articles: & $\begin{array}{c}1.23 \\
(\mathrm{MIN}=1 \\
\mathrm{MAX}=6)\end{array}$ & $\begin{array}{c}1.63 \\
(\mathrm{MIN}=1 ; \\
\mathrm{MAX}=22)\end{array}$ & $\begin{array}{c}1.64 \\
(\mathrm{MIN}=1 \\
\mathrm{MAX}=8)\end{array}$ & $\begin{array}{c}1.51 \\
(\mathrm{MIN}=1 \\
\mathrm{MAX}=14)\end{array}$ & $\begin{array}{c}1.64 \\
(\mathrm{MIN}=1 ; \\
\mathrm{MAX}=21)\end{array}$ \\
\hline No of articles: & 143 & 953 & 496 & 591 & 1031 \\
\hline $\begin{array}{l}\text { No of articles in } \\
\text { Polish: }\end{array}$ & 0 & 893 & 484 & 573 & 1031 \\
\hline $\begin{array}{l}\text { Rate of co-authored } \\
\text { articles: }\end{array}$ & $29 \%$ & $19 \%$ & $21 \%$ & $20 \%$ & $13 \%$ \\
\hline $\begin{array}{l}\text { Average number of } \\
\text { authors per article: }\end{array}$ & 1.37 & 1.23 & 1.27 & 1.24 & 1.15 \\
\hline $\begin{array}{l}\text { No of components } \\
\text { (excluding isolates): }\end{array}$ & 37 & 97 & 59 & 63 & 86 \\
\hline $\begin{array}{l}\text { No of components of } \\
\text { size } 2 \text { : }\end{array}$ & $24(65 \%)$ & $68(70 \%)$ & $42(71 \%)$ & $43(68 \%)$ & $61(71 \%)$ \\
\hline $\begin{array}{l}\text { Size of largest } \\
\text { component: }\end{array}$ & 4 & 27 & 13 & 13 & 16 \\
\hline Fragmentation: & 0.986 & 0.986 & 0.986 & 0.988 & 0.988 \\
\hline
\end{tabular}

Last but not least we look at collaboration between affiliations (full results are not reported due to space limitations). It seems that there are a few leading affiliations which dominate in the network. Two of those affiliations (Faculty of Economics; University of Warsaw and Collegium of Economic Analysis, Warsaw School of Economics) are also the leaders in foreign collaboration and additionally are mutually connected by multiple ties (as well as connected with another leading affiliation, namely National Bank of Poland). The leader in terms of number of authors (both all and collaborating authors), which is Faculty of Economics and Sociology, University of Lodz, is less connected with other leading affiliations. This analyses is 
very introductory, nevertheless it indicates that even among the institutions, which are the most successful in terms of publishing outcome, different collaboration strategies are chosen, as some focus on inter-department collaboration, and some choose for bigger extent to seek external partners, both Polish and foreign. A more detailed analysis of these trends seems to be a promising line for future research.

\section{CONCLUSIONS}

It is widely acknowledged that the structure of researcher's network may importantly affect his/her performance. In particular, collaboration with other scholars may positively impact on an individual's publication record. Consequently, cooperative behaviour may be an important element of a research's publication strategy. In this paper we verify to what extent this is reflected in the patterns and trends of co-authorship in five Polish leading economic journals. The analysis covered the period 1999-2012.

The general picture that emerges from this analysis is the following. The number of articles written in collaboration is steadily increasing. We also document an increase in the average number of authors per article. Yet, compared to what we observe elsewhere (e.g. in the top economic journals in the world) the scale of collaboration is modest. Furthermore, the increase in collaborative activity which we observe is mainly due to collaboration between Polish co-authors. Moreover, almost half of this collaboration comes from one institution and this observation is stable over time suggesting that share of collaboration between different departments is not increasing. Nevertheless, the evidence we show provides some support for the fact that the community of economists in Poland is becoming more integrated. However, it also suggests that publishing in top Polish economic journals may be unattractive for foreign collaborators and/or that publishing in these journals does not require the strategy to engage in cooperation with colleagues from abroad.

The more detailed analysis based on the records from particular journals yields less consistent picture as the trends observed there are quite diverse. Here we find that collaboration is most frequent for the Argumenta Oeconomica, which has the longest record of articles published in English and does not accept papers written in Polish (as opposed to other journals in our sample). For that journal we also observe relatively the highest share of articles written with foreign collaborators, although these articles still account only for $4 \%$ of all articles published there in the analysed period.

Our analysis can be surely extended in a number of ways, which we have tried to briefly mention in the text. We hope therefore, that the presented research, followed up by other studies, may provide some contribution to the ongoing discussion about publication performance in Polish science (in particular in economics) and thus help to design institutional surrounding which can foster the development of productive types of scientific collaboration. 


\section{REFERENCES}

Abramo, G., D’Angelo, C. A., Di Costa, F. (2011). Research productivity: Are higher academic ranks more productive than lower ones? Scientometrics, 88(3), 915-928.

Acedo F.J., Barroso C., Casanueva C., Gala, J.L. (2006). Co-authorship in management and organizational Studies: An empirical and network analysis. Journal of Management Studies, 43 (5), 957-983.

Adams J.D., Black G.C., Clemmons J.R., Stephan P.E. (2005). Scientific teams and institutional collaborations: Evidence from US universities, 1981-1999. Research Policy, 34(3), 259-285.

Agrawal A., McHale J., Oettl A. (2013). Collaboration, Stars, and the Changing Organization of Science: Evidence from Evolutionary Biology, NBER Working Paper No. 19653.

Allik, J. (2003). The quality of science in Estonia, Latvia, and Lithuania after the first decade of independence. Trames, (1), 40-52.

Azoulay, P., Graff Zivin, J., Wang, J., Superstar Extinction (2010). Quarterly Journal of Economics, 125(2), 549-589.

Benett, D.M., Taylor, D.M. (2003). Unethical practices in authorship of scientific papers. Emergency Medicine (Fremantle), 15(3), 263-70.

Błocki Z., Życzkowski K. (2013). Czy można porównywać jabłka i gruszki? O danych bibliometrycznych w różnych dziedzinach nauki. Nauka, 2, 37-46.

Borgatti S.P., Everett M.G., Johnson J.C. (2013). Analyzing Social Networks. Sage, London.

Boschini A., Sjögren A. (2007). Is team formation gender neutral? Evidence from coauthorship patterns. Journal of Labor Economics, 25(2), 325-365.

Bramoulle, Y., Djebbari, H., Fortin, B. (2009). Identification of peer effects through social networks, Journal of Econometrics, 5(1), 41-55.

Bukowska, G., Łopaciuk-Gonczaryk B. (2013). Determinanty sukcesów publikacyjnych naukowców. Nauka, 3, 59-86.

Calvo-Armengol, A., Patacchini, E., Zenou, Y. (2009). Peer effects and social networks in education, Review of Economic Studies, 76, 1239- 1267.

Card, D., Della Vigna, S. (2013). Nine facts about top journals in economics. National Bureau of Economic Research, No. w18665.

Ciaian P., Pokrivcak J. (2005). Why some sectors of transition economies are less reformed than others? The case of research and education. EERI Reseach Paper Series 2.

Cosme Costa Vieira P. (2008). An economics journals' ranking that takes into account the number of pages and co-authors. Applied Economics, vol. 40, issue 7, 853-861.

Csaba L. (2002). Economics - Hungary, in Kaase, M., Sparschuh, V., Wenninger, A., (eds.): Three social science disciplines in Central and Eastern Europe: handbook on economics, political science and sociology (1989-2001). Social Science Information Centre, Berlin.

De Stefano, D., Fuccella, V., Vitale, M. P., Zaccarin, S. (2013). The use of different data sources in the analysis of co-authorship networks and scientific performance. Social Networks, 35, 370-381.

Egorov, I. (2002). Perspectives on the scientific systems of the post-soviet states: a pessimistic view. Prometheus, 20(1), 59-73.

Fafchamps, M., Van der Leij, M., Goyal, S. (2006). Scientific networks and co-authorship. 
Discussion Paper Series 256. University of Oxford, Department of Economics. Available at: http://www.economics.ox.ac.uk/materials/working papers/paper256.pdf.

Fafchamps, M., Goyal, S., van der Leij, M.J. (2010). Matching and Network Effects. Journal of European Economic Association, 8(1), 203-231, 2010.

Fox, M. F., Gender, family characteristics, and publication productivity among scientists. Social Studies of Science, 35(1), 131-150.

Goldfinch, S., Dale, T., DeRouen, K. (2003). Science from the periphery: Collaboration, networks and 'Periphery Effects' in the citation of New Zealand Crown Research Institutes articles, 1995-2000. Scientometrics, 57(3), 321-337.

Goyal S., Van Der Leij M. J., Moraga J.L. (2004). Economics: An emerging small world. Tinbergen Institute Discussion Papers 04-001/1, Tinbergen Institute.

Goyal S., Van Der Leij M.J., Moraga González J.L. (2006). Economics: An emerging small world. Journal of Political Economy, 114(2), 403-412.

Gossart, C., Ozman, M. (2009). Co-authorship networks in social sciences: The case of Turkey. Scientometrics, 78(2), 323-345.

Hakala, J. (1998). Internationalisation of Science: Views of the Scientific Elite in Finland. Science Studies, 11(1), 52-74.

Hamermesh, D. S. (2012). Six Decades of Top Economics Publishing: Who and How? NBER Working Paper No. 18635. Available at: http://www.nber.org/papers/w18635.

He, Z. L., Geng, X. S., Campbell-Hunt, C. (2009). Research collaboration and research output: A longitudinal study of 65 biomedical scientists in a New Zealand university. Research Policy, 38(2), 306-317.

Jones, B. F. (2009). The burden of knowledge and the "death of the renaissance man": Is innovation getting harder? Review of Economic Studies, 76(1), 283-317.

Kierzek R. (2008). Polska nauka w indeksie Hirscha. Forum Akademickie, 6-7, 29-35.

Kierzek R. (2009). Jak porównać „apples and oranges”, czyli o różnych metodach analizy publikowalności i dorobku naukowego. Sprawy nauki, 2 (143), 33-41.

Kozak, M., Bornmann, L., Leydesdorff, L. (2013). How have the Eastern European countries of the former Warsaw Pact developed since 1990? A bibliometric study. Working Paper.

Kuzhabekova, A. (2011). Impact of co-authorship strategies on research productivity: A social-network analysis of publications in russian cardiology. Dissertation, University of Minnesota.

Kyvik, S. (1991). Productivity in academia: Scientific publishing at Norwegian universities. Norwegian University Press, Oslo.

Laband D.N., Tollison R.D. (2000). Intellectual collaboration. Journal of Political Economy, 108(3), 632-662.

Laband, D. N., Tollison, R. D., Karahan, G. (2002). Quality control in economics. Kyklos, 55(3), 315-334.

Larivie're, V., Gingras, Y., Archambault, E. (2006). Canadian collaboration networks: A comparative analysis of the natural sciences, social sciences and the humanities. Scientometrics, 68(3), 519-533.

Lee S., Bozeman B. (2005). The impact of research collaboration on scientific productivity. Social Studies of Science, 35(5), 673-702.

Leimu, R., Koricheva, J. (2005). Does scientific collaboration increase the impact of ecological articles?. BioScience, 55(5), 438-443.

Lissoni, F., Mairesse, J., Montobbioy, F., Pezzoniz, M. (2011). Scientific productivity 
and academic promotion: a study on French and Italian physicists. Industrial and Corporate Change 20 (1), 253-294.

Łopaciuk-Gonczaryk B. (2014). Collaboration strategies for publishing articles in top journals - a study of Polish scientists in economics. Manuscript.

Macháček, M. (2004). Komparace tematické struktury časopiseckých publikací českých a evropských ekonomů, Politická ekonomie, 52, 1, 74-90.

Mali F., Kronegger L., Ferlogoj A. (2010). Co-authorship trends and collaboration patterns in the Slovenian sociological community. Corvinus Journal of Sociology and Social Policy, vol.1, 2, 29-50.

McDowell, J. M., Smith. J. K. (1992). The Effect of Gender Sorting on Propensity to Coauthor: Implications for Academic Promotion. Economic Inquiry, 30, 1, 68-82.

McFadyen, A., Cannella, A. (2004). Social capital and knowledge creation: Diminishing returns of number and strength of exchange relationships. Academy of Management Journal 47 (5), 735-746.

Moody, J. (2004). The Structure of a Social Science Collaboration Network: Disciplinary Cohesion from 1963 to 1999. American Sociological Review 69 (2), 213-238.

Must, U. (2012). Alone or together: Examples from history research. Scientometrics, 91(2), 527-537.

Newman M. E. (2004). Coauthorship networks and patterns of scientific collaboration. Proceedings of the National Academy of Sciences of the United States of America, 101 (Suppl. 1), 5200-5205.

Olechnicka A., Płoszaj A. (2008). Polska nauka w sieci? Przestrzeń nauki i innowacyjności. Raport z badań. Warszawa, 1-103.

Osiewalska A. (2008) Analiza cytowań z wybranych polskojęzycznych czasopism ekonomicznych, in: Zarządzanie informacją w nauce, 244-256. Wydawnictwo Uniwersytetu Śląskiego, Katowice.

Puuska, H. M., Muhonen, R., Leino, Y. (2014). International and domestic co-publishing and their citation impact in different disciplines. Scientometrics, 98(2), 823-839.

Rumsey-Wairepo, A (2006). The Association Between Co-authorship Network Structures and Successful Academic Publishing Among Higher Education Scholars. Dissertation, Department of Educational Leadership and Foundations, Brigham Young University.

Schubert, T., Sooryamoorthy, R. (2010). Can the centre-periphery model explain patterns of international scientific collaboration among threshold and industrialised countries? The case of South Africa and Germany. Scientometrics, 83(1), 181-203.

Schymura, M. Löschel, A. (2012). Investigating JEEM empirically: A story of coauthorship and collaboration. ZEW Discussion Papers, 12-29.

Scott John P. (2000). Social Network Analysis: A Handbook. Sage Publications Ltd, London.

Teodorescu, D., Andrei, T. (2011). The growth of international collaboration in East European scholarly communities: a bibliometric analysis of journal articles published between 1989 and 2009. Scientometrics, 89, 711-722.

Tien F., Blackburn R. (1996). Faculty Rank System, Research Motivation, and Faculty Research Productivity: Measure. Journal of Higher Education, 67, 1, 2-22.

Turnovec, F. (2002). Economics in the Czech Republic, in Kaase, M., Sparschuh, V., Wenninger, A., (eds.): Three social science disciplines in Central and Eastern Europe: handbook on economics, political science and sociology (1989-2001). Social Science Information Centre, Berlin. 
Ukrainski, K., Masso, J., Kanep, H. (2014). Cooperation patterns in science within Europe: the standpoint of small countries. Scientometrics, 99(3), 845-863.

Waldinger, F. (2010). Quality Matters: The expulsion of students and the consequences for Phd student outcomes, Journal of Political Economy, 118(4), 787-831.

Wasserman S., Faust K. (2008). Social Network Analysis: Methods and Applications. Cambridge University Press, New York.

Welsh, M. J., Bremser, W. G. (2005). Accounting faculty research collaboration: a study of relationship benefits and gender differences. Global Perspectives on Accounting Education, 2(1), 19-36.

Wilkin J. (2013). Ocena parametryczna czasopism naukowych w Polsce - podstawy metodologiczne, znaczenie praktyczne, trudności realizacji i perspektywy. Nauka, nr 1, 45-54.

Wolszczak-Derlacz J., Parteka A. (2005). Produktywność naukowa wyższych szkół publicznych w Polsce. Bibliometryczna analiza porównawcza, Raport Ernst \& Young, Warszawa.

Wróblewski A.K. (2005). Nauka w Polsce według rankingów bibliometrycznych. Nauka, $\mathrm{nr} 2,13-28$.

Wuchty S., Jones B., Uzzi B. (2007). The Increasing Dominance of Teams in Production of Knowledge. Science, 316,1036-1039.

Yegorov, I. (2009). Post-Soviet science: Difficulties in the transformation of the R\&D systems in Russia and Ukraine. Research Policy, 38, 600-609. 


\section{SUPPLEMENTARY DATA}

Figure 4. Collaboration trends in 5 Argumenta Oeconomica, Bank i Kredyt and Ekonomista: 1999-2012
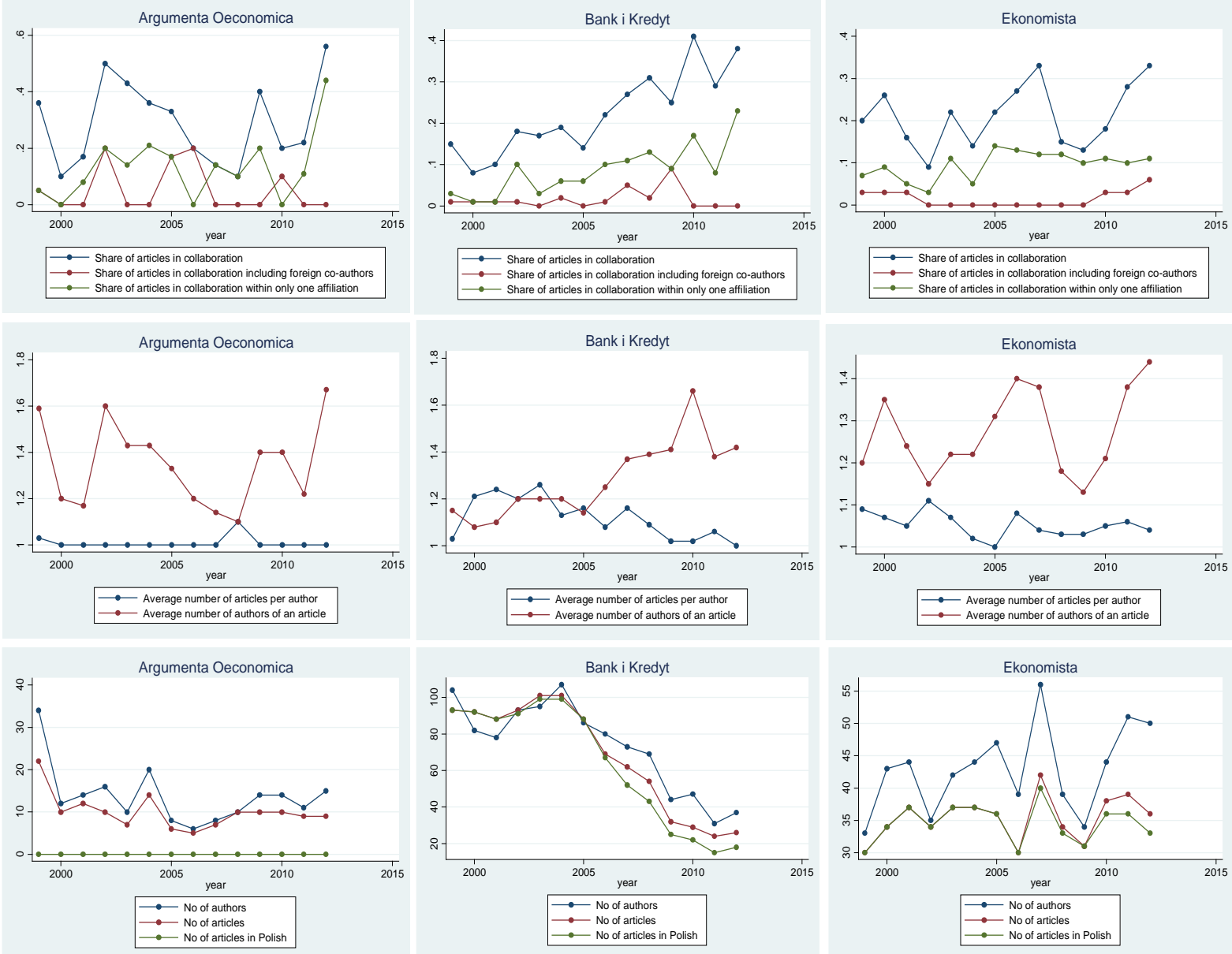
Figure 5. Collaboration trends in 5 Gospodarka Narodowa and Polityka Społeczna: 19992012
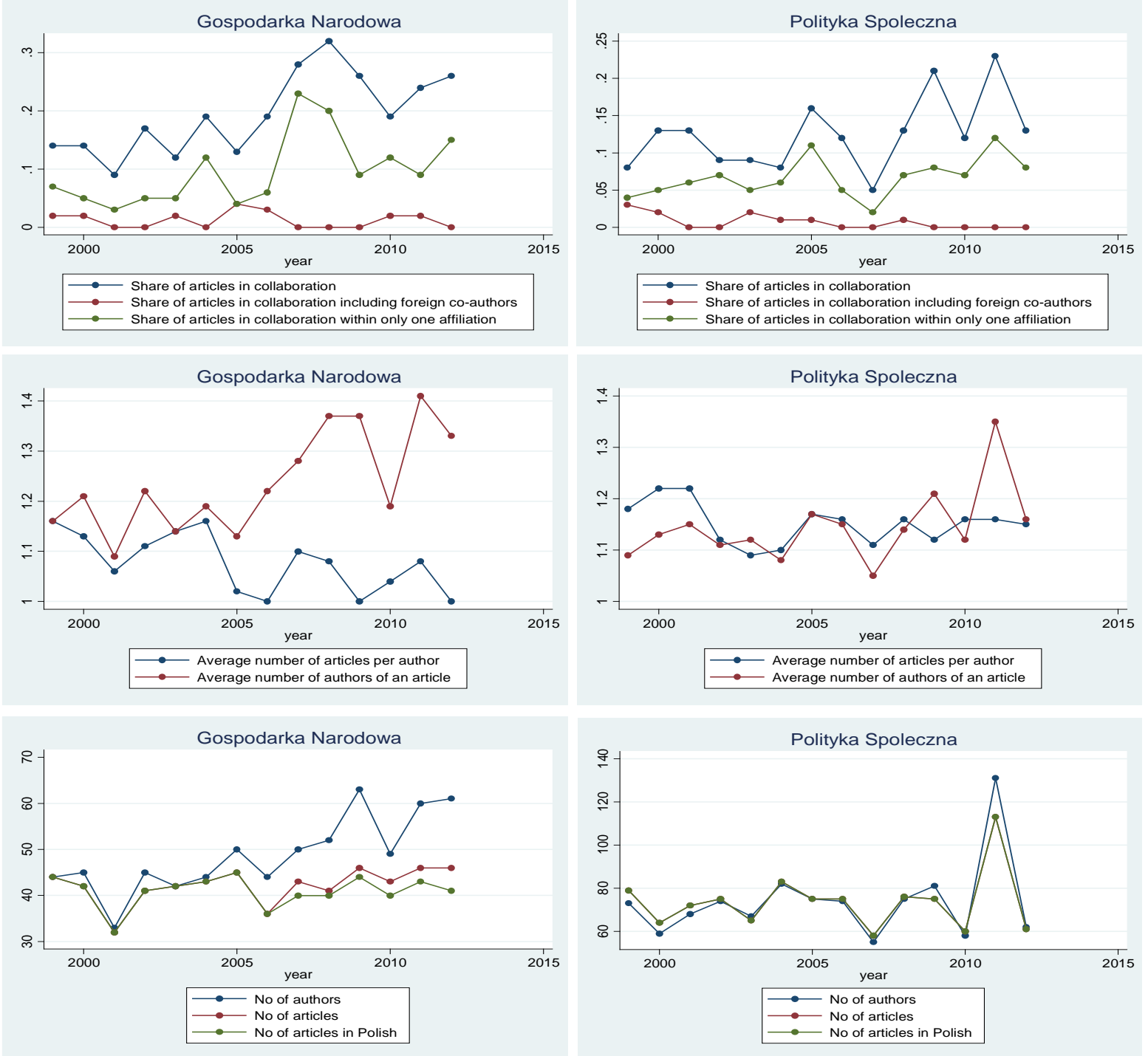


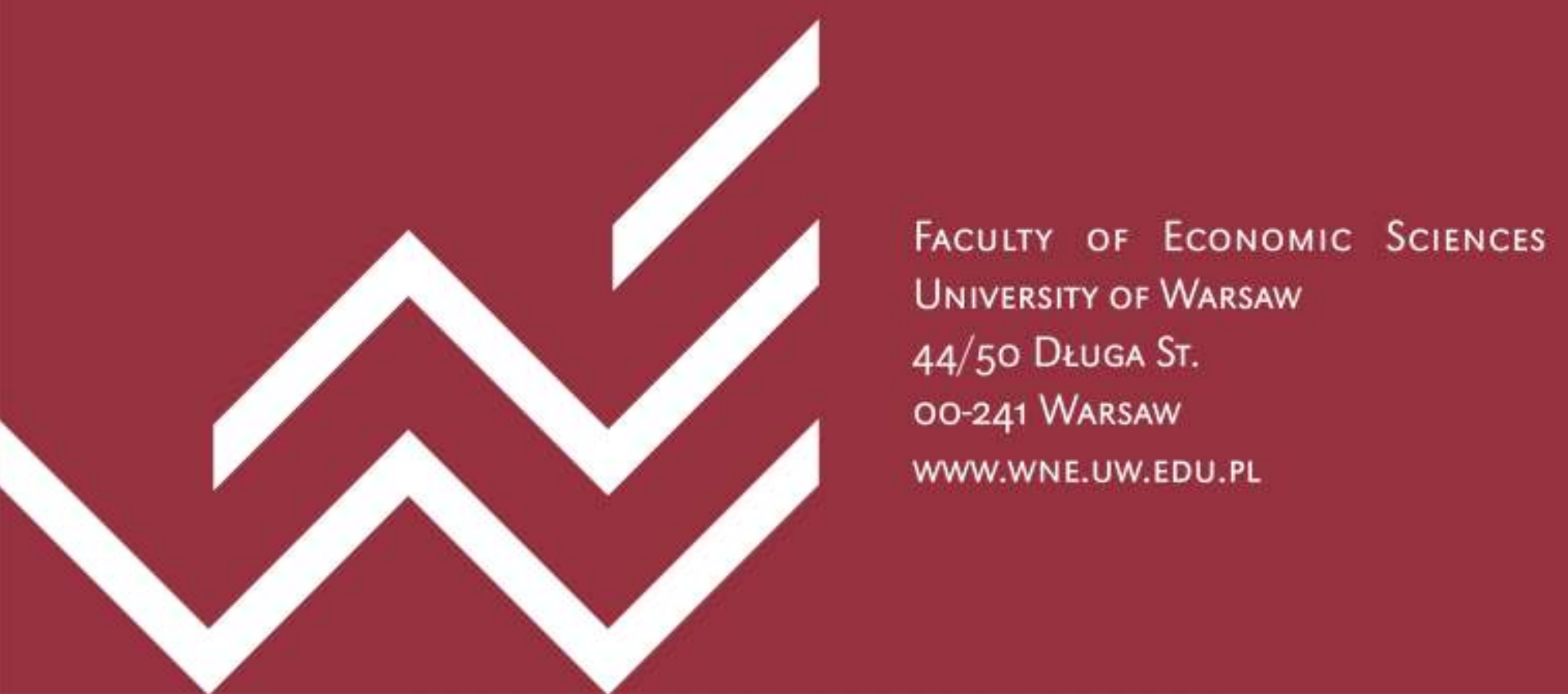

